\title{
Narcotráfico Securitizado: Operação Ágata 5
}

\section{Caroline Cordeiro Viana e Silva ${ }^{1}$}

\section{RESUMO}

O objetivo principal do paper é apresentar, brevemente, a securitização do narcotráfico no Estado brasileiro e o papel das Operações Ágata dentro deste processo. De maneira específica, a contribuição da Ágata 5 como parte do tema securitizado. Os principais resultados alcançados são: a constatação da prioridade da região centro-oeste para o combate a narcotráfico e a deficiência na fiscalização permanente da fronteira.

Palavras-chave: Operação Ágata; Plano Estratégico de Fronteira; Securitização

O Estado brasileiro aumenta seus esforços no combate ao tráfico ilícito de entorpecentes a cada ano e, mais especificamente, é possível observar intensificação de políticas antidrogas a partir de 2004. Este marca o início de um período de intensificação por ser o ano de lançamento da Lei do Abate, que foi seguida pela criação da Política Nacional Sobre Drogas em 2005, seguida pela criação da Lei Antidrogas em 2006, tendo, seu ápice, em 2011 com o Plano Estratégico de Fronteira.

Tendo, como base teórica, a Escola de Copenhague, é possível perceber que o combate ao narcotráfico passou por um processo de securitização. Processo de securitização é o movimento que leva ameaças além das regras pré-estabelecidas pela política. Determinado tema pode ser enquadrado como "não politizado", "politizado" e "securitizado". Por "não politizado" entende-se que o tema não conta com o envolvimento do Estado em suas discussões, por "politizado" quando um tema está na agenda do Estado, mas demanda apenas manobras previstas na política estatal e,

\footnotetext{
${ }^{1}$ Graduada em Relações Internacionais, especialista em Sociologia Política pela UFPR e mestranda do Programa de Pós-Graduação em Ciência Política da mesma instituição. 
"securitizado", quando transpassa as regras políticas e exige uma ação emergencial e imediata. A securitização pode ser vista como uma versão extremada da politização.

No caso do combate ao narcotráfico, no Brasil, é possível perceber que, até o ano de 2004, o tema era politizado, pois fazia parte da agenda, mas era tratado dentro das regras cotidianas da política, até se intensificar em 2004. A Lei do Abate é um marco pois prevê, em seu texto, a atuação emergencial do Estado, começa-se a falar em ação imediata neste momento até, por fim, o Plano Estratégico de Fronteira marcar a securitização do tema, pois define, em seu escopo, ações imediatas reais de combate a ilícitos, como também prevê o deslocamento das Forças Armadas de suas tarefas constitucionais para ações de emergências. Estas ações são descritas no Plano Estratégico de Fronteira como Operações Ágatas.

As Operações Ágata são divididas em duas fases. A primeira prevê o emprego das Forças Armadas em coordenação com os Centros de Operações Conjuntas. São previstas medidas preventivas e repressivas em áreas previamente determinadas. A segunda fase prevê acordos com os países fronteiriços.

Os objetivos estratégicos da Operação Ágata são: 1) Neutralização do crime organizado; 2) Redução dos índices de criminalidade; 3) Coordenação do planejamento e execução de operações militares e policiais; 4) Cooperação com países fronteiriços; 5) Intensificação da presença das Forças Armadas; 6) Apoio à população.

A Operação Ágata 1 ocorreu na faixa de fronteira da Amazônia, região norte, mais especificamente entre os municípios de Tabatinga e São Gabriel da Cachoeira, com a participação de três mil e quinhentos militares do Exército, Marinha e Aeronáutica², durante o mês de agosto de 2011. A Ágata 2 ocorreu nas fronteiras Sul e Centro-Oeste, mais especificamente nos estados de Mato Grosso do Sul, Paraná, Santa Catarina e Rio Grande do Sul, envolvendo, aproximadamente, oito mil homens das Forças Armadas, de setembro a outubro de $2011 .^{3}$

A Ágata 3 ocorreu nos estados de Mato Grosso, Mato Grosso do Sul e Rondônia, de novembro a dezembro de 2011. Foram deslocados cerca de 6.500 homens das Forças

\footnotetext{
2 Disponível em: http://www.fab.mil.br/portal/capa/index.php?mostra=8001 acessado em: 10/06/12.

3 Disponível em: http://www.brasil.gov.br/noticias/arquivos/2011/09/26/operacao-agata-2-reduzindice-de-criminalidade-na-fronteira-com-o-paraguai. Acessado em: 10/06/12

Conjuntura Global, Curitiba, Vol. 1, n.2, out./dez., 2012, p. 37-40. 
Armadas para esta Operação. ${ }^{4}$ E, por fim, a Ágata 4 ocorreu, novamente, na região norte do país, desta vez abrangendo os estados de Amapá, Pará, Amazonas e Roraima, nos meses de março e abril de 2012, empregando cerca de seis mil e quinhentos militares. 5

A Operação Ágata 5 ocorreu de 05 a 20 de agosto de 2012 nos estados de Mato Grosso do Sul, Paraná, Santa Catarina e Rio Grande do Sul. Com o sucesso das operações, a quinta Ágata foi programada e executada em maior proporção, enquanto as quatro operações anteriores mobilizaram entre 3 e 6 mil militares, a Ágata 5 mobilizou, aproximadamente, 17 mil militares da Marinha, Exército e Aeronáutica. 0 resultado da operação foram 31 prisões, apreensão de 6 toneladas de entorpecentes, o recolhimento de 182 carros e embarcações numa área de 3,9 mil quilômetros de fronteira.

De acordo com o balanço divulgado pelo governo federal, foram feitos ações de fiscalização de aeródromos e patrulhamento em rios, rodovias e estradas vicinais. Ocorreram 191.868 apreensões, vistorias e revistas, 148 inspeções em aeródromos, combustível de aviação, aeronaves e pilotos. Foram feitos 879 inspeções em acampamentos ribeirinhos, foram montados 2.274 postos de bloqueio e controle de estradas e fluviais e foram realizados 19 interceptações aéreas.

Com a analise de todos esses dados, é possível chegar a duas principais conclusões. A primeira é que as fronteiras brasileiras precisam de maior fiscalização constante, de caráter permanente e não apenas como uma ação emergencial. É possível perceber isso ao constatar que, em apenas 15 dias, foram apreendidos 6 toneladas de entorpecentes, um número muito alto para um período curto de força tarefa. Se, em apenas 15 dias, foi possível apreender 6 toneladas, com esforço contínuo ao longo do ano, evitar-se-ia a circulação de uma quantidade exorbitante de drogas em território nacional.

A segunda conclusão que se pode tirar é que, junto à Amazônia, a região centrooeste é prioritária para o combate a drogas, pois, de cinco Ágatas, esta região esteve presente em duas delas. Isso demonstra que, não apenas a fronteira com a Colômbia é delicada, como também a fronteira com a Bolívia e Peru tem apresentado uma situação delicada e inconstante.

\footnotetext{
${ }^{4}$ Disponível em: http://www.fab.mil.br/portal/capa/index.php?mostra=9247. Acessado em: 10/06/12

${ }^{5}$ Disponível em: http://www.agata4.aer.mil.br/index.php/operacao. Acessado em: 10/06/12

Conjuntura Global, Curitiba, Vol. 1, n.2, out./dez., 2012, p. 37-40.
} 


\section{Referências Bibliográficas}

BRASIL. Operação Ágata 2, 2011. Disponível em: http://www.brasil.gov.br/noticias/arquivos/2011/09/26/operacao-agata-2reduz-indice-de-criminalidade-na-fronteira-com-o-paraguai acessado em: 10/06/2012.

BRASIL. Operação Ágata 4, 2012. Disponível em: http://www.agata4.aer.mil.br/index.php/operacao, acessado em: 10/06/2012.

BRASIL. Operação Ágata 5, 2012. Disponível em: https://www.defesa.gov.br/index.php/noticias-do-md/2455282-21082012-defesaagata-5-termina-com-31-pessoas-presas-e-6-toneladas-de-drogasapreendidas.html, acessado em: 01/12/2012.

BUZAN, Barry; WAEVER, Ole; WILDE, Jaap de. Security: a new framework for analysis. Boulder: Lynne Reinner Publishers, 1998.

FORÇA AÉREA BRASILEIRA. Operação Ágata 1, 2011. Disponível em: http://www.fab.mil.br/portal/capa/index.php?mostra=8001, acessado em: 10/06/2012.

FORÇA AÉREA BRASILEIRA. Operação Ágata 3, 2011. Disponível em: http://www.fab.mil.br/portal/capa/index.php?mostra=9247, acessado em: 10/06/2012. 